Smoke Screens: Is There a Correlation between Migration Euphemisms and the Language of

Detention

Global Detention Project Working Paper No. 5

By Mariette Grange

September 2013 
The Global Detention Project (GDP) is a research initiative that tracks states' use of detention in response to global migration. Based at the Graduate Institute's Programme for the Study of Global Migration in Geneva, Switzerland, the GDP's aims include: (1) providing researchers, advocates, and journalists with a measurable and regularly updated baseline for analysing the growth and evolution of detention practices and policies; (2) encouraging scholarship in this field of immigration studies; and (3) facilitating accountability and transparency in the treatment of detainees.

(c) Global Detention Project 2013

Global Detention Project

Programme for the Study of Global Migration

Graduate Institute of International and Development Studies

P.O. Box 136

$\mathrm{CH}-1211$ Geneva 21

Switzerland

Tel: +41229084556

Fax: +41229084594

http://www.globaldetentionproject.org/

Mariette Grange is a senior researcher at the Global Detention Project based at the Graduate Institute's Programme for the Study of Global Migration. A long-time human rights practitioner, Grange is also trained in linguistics. The author would like to thank

Michael Flynn and Eve Lester for their helpful comments on this working paper.

Research for this paper was made possible in part by support from Zennström Philanthropies, the Oak Foundation, and the Open Society Foundations.

The Global Detention Project Working Paper Series is edited by Michael Flynn. 


\section{Smoke Screens: Is There a Correlation between Migration Euphemisms and the Language of Detention?}

SUMMARY: Discursive strategies used to describe people moving across borders can have consequences on their well-being, including limiting their access to legal procedures. This Global Detention Project working paper points to an apparent paradox in these strategies: While language used to describe migrants and asylum-seekers is often euphemistic (or dysphemistic), tending to dehumanise them, language used to characterize their treatment in custody appears aimed at shielding detention from scrutiny. The paper suggests that in the field of immigration detention, the role and impact of misleading language on policy and perception appears to be quite significant and merits more attention from scholars and advocates. 


\section{Introduction}

The practice of immigration detention has spread to most parts of the world, but the language surrounding this type of government response to migration pressure-perceived or real-is often euphemistic and opaque. The semantic field used to describe and regulate immigration detention often fails to convey the realities of deprivation of liberty and the conditions of detention. Thus, one can study the official discourse and immigration legislation of important detaining countries that have large populations of men, women, and sometimes children deprived of liberty because of their immigration status and yet never observe the words "detention" or "detainee." 1

This fact raises a number of worrying questions. For instance, does the effort to shield detention practices behind misleading terminology decrease transparency with respect to the treatment of detainees, thereby increasing their vulnerability to mistreatment? States and inter-governmental agencies can employ discursive strategies to pursue extra-linguistic aims and mask serious deficiencies in law and practice. Similarly, deploying new terminology or attributing new meaning to existing words and phrases can potentially lead to the exclusion of immigration detainees from procedural guarantees and breaches of their human rights.

Nevertheless, little research has been done to try to understand the origins and specifics of discursive trends in immigration detention and whether they have had an impact on national policies and practices. This Global Detention Project working paper seeks to begin to fill this gap. It argues that the terminology used in official and public discourses tends to demonise migrants and asylum seekers, and helps justify the at times harsh treatment meted out by authorities. The paper then assesses how, in contrast to the demonization of migrants, states curiously tend to avoid being frank about how these migrants are treated. A case in point is detention: The language used to designate detention practices is often opaque or misleading, which can have negative consequences for detainees by helping make them invisible to both the public and in law. Ultimately, the paper argues that language deserves closer scrutiny because it appears to play a pivotal role in shaping, justifying, and rationalising policies and practices related to immigration detention.

\section{The labelling of migrants}

It is often the case that before migrants and asylum seekers, including stateless persons, find themselves behind bars in detention centres, they have already been characterized in official reports and popular media as disingenuous, non-deserving, or even as delinquents or criminals. An important tool enabling this characterization is euphemistic-or, rather, dysphemistic-language.

\footnotetext{
${ }^{1}$ For a discussion of efforts to surmount some of these linguistic challenges and establish rigorous criteria for coding detention regimes, see Michael Flynn, "An Introduction to Data Construction on Immigration-related Detention," Global Detention Project, July 2011.

http://www.globaldetentionproject.org/fileadmin/publications/GDP_data_introduction_v2.pdf
} 
Euphemism enables a symbolic legitimisation that helps soften perceptions of and approaches to tough issues or taboo topics by avoiding language that may have a negative connotation. Euphemisms can also serve as positive, polite, or politically correct stylistic devices, like saying "senior citizens" for older people, "social movements" for "strikes," and "differently abled" for those formerly described as "disabled" or "handicapped."

More dramatically, euphemisms can be used to mask proscribed conduct or treatment. Post-9/11 interrogation policies in the United States included the use of "enhanced," "stress and duress," and "counter-resistance" techniques, which included torture. The absence of redress for these actions seems to be part of a failure to confront reality, which itself may be a consequence of using misleading words to denote torture. In a 2012 ruling, a U.S. federal judge argued that allegations made by two former detainees held by the U.S. military in Iraq "easily" qualified as "torture" and that "this shameful fact should not be minimized by using euphemisms such as the term "harsh interrogation techniques," as the court's majority had done when blocking the men's lawsuit. ${ }^{2}$

In contrast to most euphemistic speech, language used to discuss migration and asylum is often dysphemistic - that is, it connotes a negative quality. Whether triggering or reflecting populist rhetoric, negative migration and asylum discourses have become a tool to justify and legitimate tough policy responses by demonising policy targets, thereby symbolically legitimising the harsh effects of those responses. For instance, during the 2005 British election campaign, which saw broad use of terms like "bogus" and "illegals" to describe asylum seekers and undocumented persons, Conservative Party leader Michael Howard promised to withdraw from the 1951 Refugee Convention. ${ }^{3}$ In the United States, Immigration and Customs Enforcement (ICE), the principal investigative arm of the U.S. Department of Homeland Security, uses the term "illegal aliens." And the term "clandestine" (clandestinos) is used in parts of Europe and in Mexico. At a regional level, unauthorised migrants have been labelled "illegals" in many official EU documents for more than a decade." ${ }^{4}$ These terms arguably "criminalise" migrants and asylum seekers in public perception.

A similar trend is the effort to frame migration policy using the language of "risks" and "threats," both of which imply a need for a security-oriented approach to immigration and

\footnotetext{
${ }^{2}$ Amnesty International, "USA chronicle of immunity foretold: Time for change on counter-terrorism violations after another year of blocking truth, remedy and accountability," 17 January 2013.

http://www.amnesty.org/es/library/info/AMR51/003/2013/en

${ }^{3}$ According to the Conservative Election Manifesto 2005: “On asylum, a Conservative Government will not allow outdated and inflexible rules to prevent us shaping a system which is more humane, more likely to improve community relations and better managed. So we will take back powers from Brussels to ensure national control of asylum policy, withdraw from the 1951 Geneva Convention, and work for modernised international agreements on migration." ${ }^{4}$ See, for example, European Union, "Summary of Readmission Agreements with Eastern European Countries," available at the Europa website, "Summaries of EU legislation."

http://europa.eu/legislation_summaries/justice_freedom_security/free_movement_of_persons_asylum_immigration/I 14163_en.htm (accessed 18 September 2013). The summary states, "These agreements aim to facilitate the return of illegal immigrants originating from Georgia, Moldova, and Ukraine to their countries, and also illegal migrants who have transited through Georgia, Moldova, or Ukraine before entering the EU. See also, Commission of the European Communities, "Green Paper on a Community Return Policy on Illegal Residents," COM(2002) 175 final, 10 April 2002. http://europa.eu/legislation_summaries/other/I33192_en.htm. According to the Green Paper, "The Commission argued that, as part of a comprehensive immigration policy, the adoption of common procedures for labour migrants could to a certain extent also reduce pressure on channels for humanitarian admission and that illegal migrants would be further deterred by more effective joint action against smuggling and trafficking."
} 
asylum. This can encourage a siege-mentality in the population, which is then nurtured by increasingly stringent detention policies. This type of terminology is used broadly in Canada and Australia. The Canada Border Service Agency (CBSA), which describes itself as an "integral part of the Public Safety Portfolio," has been mainstreaming a "risk-based approach" to respond to "international threats," including migrant smuggling. ${ }^{5}$ Irregular migrants arriving in a "designated human smuggling operation" are placed in mandatory detention for one year without review of the detention order and more than one third of immigration detainees are actually held in some 40 prisons.

In Australia, "unauthorized maritime arrivals" (mainly from Afghanistan, Sri Lanka, Pakistan, and Iran) represent a minority of irregular migrants in the country. However, they are subject to more severe measures than visa "overstayers" who may be westerners or wealthier Asians arriving by air. ${ }^{6}$ Described as "queue jumpers," people arriving by boat are portrayed as trying to steal resettlement places from "genuine" refugees in Australia. Through the "Pacific Solution" launched in 2001 (and revived in 2012), Australia has crafted "excised territories" to "strengthen territorial integrity." As a result, asylum seekers are sent for "off-shore processing." According to new legislation, all asylum seekers arriving by boat anywhere in Australia are now subject to transfer to Nauru or Papua New Guinea for processing. ${ }^{8}$

Language can also be loaded with historical references to connote presumed threats, such as the new Israeli Law for the Prevention of Infiltration, which allows the state to detain migrants—without differentiating between asylum seekers, refugees, and irregular immigrants-for three years or longer. The term "infiltrators" dates back to a 1954 law that targeted Palestinians and citizens of Lebanon, Egypt, Syria, Saudi Arabia, Jordan, Iraq, and Yemen. ${ }^{9}$

An increasing number of major media, particularly in the United States, have apparently begun to recognize the potentially adverse impact of opportunistic negative language in the field of migration. In February 2013, the Associated Press news agency decided to drop the world "illegal" when referring to migrants in its authoritative AP Stylebook, using the term only when describing the effort to enter a country without authorization. ${ }^{10}$ The New York Times, NBC News, The Huffington Post, and Fox News Latino, as well as networks like $A B C$ News and $C N N$, have also begun recommending that journalists take the context into

\footnotetext{
${ }^{5}$ CBSA, Canada Border Service Agency, 2011-12 Part III - Departmental Performance Reports (DPR). http://www.cbsaasfc.gc.ca/agency-agence/reports-rapports/dpr-rmr/2011-2012/report-rapport-eng.html\#s2x6.

${ }^{6}$ Wayne Flower and Ben Packham, "Illegal immigrants who overstay visas will no longer be put in detention camps," Herald Sun, 4 May 2009. http://www.news.com.au/national-news/no-detention-for-visa-dodgers/story-e6frfkvr1225708050188

${ }^{7}$ Martha Augoustinos and Danielle Every, "The Language of 'Race' and Prejudice: A Discourse of Denial, Reason, and Liberal-Practical Politics," Journal of Language and Social Psychology, Volume 26, Number 2, June 2007.

${ }^{8}$ UNHCR, "New'"excision' law does not relieve Australia of its responsibilities towards asylum-seekers," Press Release,

22 May 2013. http://www.unhcr.org/519ccec96.html

9 Leehee Rothschild, “'Infiltrators' and the Jewish state," Mondoweiss, 12 January 2012.

http://mondoweiss.net/2012/01/infiltrators-and-the-jewish-state.html

${ }^{10}$ Paul Colford, “'Illegal immigrant' no more,” Associated Press, 4 February 2013. http://blog.ap.org/2013/04/02/illegalimmigrant-no-more/
} 
consideration to reflect the legal status of migrants. ${ }^{11}$ Google's free translation service recently stopped translating the Spanish term for "undocumented" with "illegal immigrant." 12

International and regional rights bodies have long insisted on the importance of using careful language to denote migrants. For example, in 1975 the UN General Assembly recommended that all UN bodies use "non-documented or irregular migrants/workers" as a standard phrase. ${ }^{13}$ More recently, a 2011 paper commissioned by the Council of Europe's Commissioner for Human Rights, concluded: "The choice of language is very important to the image which the authorities project to their population and the world. Being an immigrant becomes associated, through the use of language, with illegal acts under the criminal law. ... Illegal immigration as a concept has the effect of rendering suspicious in the eyes of the population (including public officials) the movement of persons across international borders. The suspicion is linked to criminal law-the measure of legality as opposed to illegality." In 2013, the Special Rapporteur on the Human Rights of Migrants warned that language choices can easily lead to stereotyping, which can in turn fuel xenophobic discourses and violence against migrants. ${ }^{14}$

These institutional warning signs-bolstered by numerous civil society campaigns on this topic $^{15}$-about how derogatory language can distort public perception and fuel xenophobic reactions seemingly have had little effect on the policies of many states and international actors. Nevertheless, it seems clear that negative labelling of migrants tends to render them suspicious and serves as a convenient prop for advocating harsh treatment.

\section{Euphemisms and immigration detention}

Given the effort that has been put into demonising migrants in public and official discourses, it seems logical that states would be willing to clearly and accurately characterize their treatment when in custody. After all, if the asylum seeker is a "criminal," is it not reasonable that he or she be put behind bars and eventually expelled? Thus, it is puzzling that many countries around the world as well as their partners in the international community have gone to great lengths to shield these aspects of migration control regimes, making broad use of "hospitality euphemisms" to characterise detention and deportation practices. One analyst at the Global Detention Project has theorised that this effort reveals liberal states'

\footnotetext{
${ }^{11}$ Chris Patterson, "Language like 'illegal immigrant' seen as a challenge during immigration debate," CBS 58 News, 4 April 2013. http://www.cbs58.com/news/national-news/Language-like-illegal-immigrant-seen-as-a-challenge-duringimmigration-debate--201455881.html

12 Portada, “Google Please Learn how to Translate," 22 August 2013. http://www.portada-

online.com/2013/08/22/google-please-learn-how-to-translate/

${ }^{13}$ UN General Assembly, "Measures to ensure the human rights and dignity of all migrant workers," General Assembly Resolution No. 3449/XXX, United Nations, 9 December 1975. http://www.un.org/Depts/dhl/resguide/r30.htm

${ }^{14}$ François Crépeau, "Towards the 2013 High-Level Dialogue on International Migration and Development: the Legal International Framework in Place to Protect Migrants," Keynote Address. Office of the High Commissioner for Human Rights, 20 February 2013.

http://www.ohchr.org/EN/Issues/Migration/SRMigrants/Pages/HighLevelDialogueonMigrationandDevelopment.aspx ${ }^{15}$ See, for example, "No Child is Illegal," Information Platform humanrights.ch, http://www.humanrights.ch/en/Switzerland/Internal-Affairs/Groups/Children/idart_6290-content.html?zur=542; "Kein Mensch ist illegal - Köln," http://www.kmii-koeln.de/; "No One is Illegal - Montreal, Ottawa, Toronto, Vancouver," http://www.nooneisillegal.org/; "Immigrants' Rights - No Human Being is Illegal," American Civil Liberties Union, https://www.aclu.org/immigrants-rights.
} 
inherent unease-or "sovereign discomfort"-with practices that belie a core axiom of liberal democracy, the right to freedom. ${ }^{16}$

Whatever the explanation for this puzzle, efforts to characterize migration control with euphemisms is widespread at both the national and international levels. A case in point is the burgeoning discussion of "migration management." As one scholar notes, "most approaches to manage migration are out-sourced and entrusted to non-EU actors such as the IOM [International Organisation for Migration],"17 whose motto is "Managing Migration for the Benefit of All." Until recently, one was hard pressed to find any reference to the IOM's programmatic involvement in immigration detention, despite the fact that the organisation has played a role developing detention practices, including its involvement in the Pacific Solution in Australia in the early 2000s. ${ }^{18}$

At the EU level, funding lines and programmes related to migration management reveal generous support for the construction or operation of detention facilities in countries at the periphery as part of its "Neighbourhood Policy. ${ }^{19}$ In a 2005 report about Ukraine, Human Rights Watch reported that the first priorities for EU Neighbourhood Policy were cooperation in the area of justice and home affairs, and that it included "readmission and migration, border management [and] trafficking in human beings ${ }^{20}$ In EU policies, regulations and programmes on "removal," "return," and "readmission" are effectively equivalent to expulsion/deportation. In a rare public illustration that the choice of terms in EU migration related policies is part of a consciously elaborated discursive strategy, the entry on "removal" in the Glossary of the European Migration Network reads: "The enforcement of the obligation to return, namely the physical transportation out of the country. Synonym: Deportation (not preferred term to use)" [emphasis added]. ${ }^{21}$ The International Centre for Migration Policy Development (ICMPD), another inter-governmental organisation created outside the UN family which has celebrated 20 years of "innovative migration governance" is also a recipient of substantive EU funds for projects described as

\footnotetext{
${ }^{16}$ Michael Flynn, "The Hidden Costs of Human Rights: The Case of Immigration Detention," Global Detention Project Working Paper, September 2013.

${ }^{17}$ Leonhardt van Efferink, “Interview with Martin Geiger," Exploring Geopolitics, October 2010. http://www.exploringgeopolitics.org/Interview_Geiger_Martin_International_Immigration_Management_Organization _Policy_Politics_EU_Schengen_Treaty_Illegal_Human_Women_Trafficking_Minorities_Citizenship.html.

${ }_{18}$ Wendy Bacon, “Australia's 'Pacific Solution' for asylum seekers - a timeline PART ONE: 2001-2003," Pacific Media Centre, 8 August 2012. http://www.pmc.aut.ac.nz/articles/australias-pacific-solution-asylum-seekers-timeline. The IOM's 2001 financial report indicates that "Total expenditure for Asia and Oceania increased by 20.2 million (or 66 per cent) due to the Organization's involvement in emergency operations in Afghanistan and the processing of Australiabound migrants in the Pacific [emphasis added]." However, it makes no direct reference to detention-related programmes, indicating only that there were staff and office expenditures for Nauru for that year. See IOM, 84th Session of the Council (2002). http://www.iom.int/cms/en/sites/iom/home/about-iom-1/governingbodies/council/84th-session-of-the-council-2002.html

${ }^{19}$ For example, in Ukraine, "despite the low number of readmissions of third-country nationals, in 2011 the EU launched a 30-million-Euro new construction programme to further expand the detention infrastructure in relation to readmission." Global Detention Project, Ukraine Detention Profile, December 2012.

http://www.globaldetentionproject.org/countries/europe/ukraine/introduction.html

${ }^{20}$ Human Rights Watch, "Ukraine: On the Margins: Rights Violations against Migrants and Asylum Seekers at the New Eastern Border of the European Union,". Volume 17, No. 8(D). November 2005.

http://www.hrw.org/sites/default

${ }^{21}$ EMN Glossary \& Thesaurus. http://ec.europa.eu/dgs/home-affairs/what-we-

do/networks/european_migration_network/glossary/index_r_en.htm (accessed 17 September 2013).
} 
migration management and border control, some of which unambiguously deal with detention. $^{22}$

Specifically regarding detention, Global Detention Project researchers have noted a clear trend in many countries to cast deprivation of liberty in a favourable-or, at the very least, less menacing-light. There are numerous examples one can point to. In Turkey immigration detention was for many years officially labelled "accommodation in guesthouses for foreigners" (the country recently adopted the term "removal centres"). In Ukraine, detention is described in the law on the Legal Status of Foreigners and Stateless Persons as "accommodation in the temporary stay facilities for foreigners and stateless persons who stay in Ukraine illegally." Mexican law provides for the "hosting" of irregular migrants in "migratory stations" (migrantes alojados en estaciones migratorias). In Malaysia, immigration detention centres are called "depots." New regulations in Spain seek to change the current name for detention centres, "foreigners internment centres" (centros de internamiento de extranjeros), to "centres for the controlled stay of foreigners" (centros de estancia controlada de extranjeros). And in Bulgaria, detention takes place in "specialized homes for temporary accommodation of foreigners," which the law calls "coercive accommodation." One observer in Bulgaria reported that this confusing terminology led a journalist from the Bulgarian state television to describe the detention centre as a "charity home."23

In some cases, the use of novel language to describe immigration detention may have resulted from the efforts of authorities to denote a relatively new practice. For instance, in the early 1980s, France adopted its first laws regulating the practice of immigration detention and coined a new term to describe both the practice and the facilities used: rétention. However, this word, as well as the phrase "waiting zones" at French international airports, suggests that such persons are merely "retained," not detained (i.e. France maintains the legal fiction that they are free anytime to leave the country and go back to their own). ${ }^{24}$

International and regional agencies have been similarly culpable. The IOM's Migration Initiatives 2012 includes a project that the organisation describes as "support for the Armenian Government to establish migrant accommodation centres. ... The project will support the Government of Armenia in enhancing its reception of refugees and asylumseekers and assist it in establishing border reception centres operating according to the international standards for treatment and detention of irregular migrants." Although the term "detention" is used, the key terms are clearly "accommodation" and "reception." 25 Likewise, an EU twinning project entitled "Support to Turkey's Capacity in Combating Illegal Migration and Establishment of Removal Centres for Illegal Migrants" refers to "detention centres" only once, and then to "removal centres" 30 times. $^{26}$

\footnotetext{
${ }^{22}$ EuropeAid, "Financial Contributions of EuropeAid to Other International Organisations from May 2007 till end $2010 . "$

${ }^{23}$ Valeria Ilareva, "Immigration Detention in International Law and Practice (In search of solutions to the challenges faced in Bulgaria)," Statewatch, 2008. (Available at http://www.ulb.ac.be/assoc/odysseus/cvlLAREVAuk.html.)

${ }^{24}$ Anafé, la Cimade, and Gisti (MIGREUROP Network), “L'enfermement des étrangers en France," UNDATED. http://www.anafe.org/doc/generalites/centred\%27enfermement.html

${ }^{25}$ International Organization for Migration, “Migration Initiatives 2012," December 2011.

http://publications.iom.int/bookstore/index.php?main_page=product_info\&cPath=34\&products_id=762

${ }^{26}$ Standard Summary Projet Fiche IPA decentralised National Programmes, Project Number: TR 0702 16, Twinning No: TR 07 IB JH 05
} 
Additionally, EU directives appear to be intentionally vague on the subject. The Directive on Minimum Standards for the Reception of Asylum Seekers provides that "Member States may confine [emphasis added] an applicant to a particular place in accordance with their national law." Although there are references to detention in the directive, this language suggests a blurring of the line between practices perceived to constitute "detention" and those regarded as restrictions of movement not amounting to detention. In an effort to clarify the meaning of legal provisions, the European Parliament argued that the "Return Directive's" initial wording on "temporary custody" should be changed to "detention" because it could last up to six months, which was far from temporary. ${ }^{27}$

In contrast to this trend, some migrant rights activist have adopted terms that appear to be intentionally provocative. For example, Migreurop, a Euro-Mediterranean civil society network, produces a map of "camps" in the Euro-Mediterranean region. The group acknowledges that the use of camps (both "open" and "closed") to designate contemporary forms of confinement and exclusion of foreigners is polemic but argues that it reflects rigorous semantics, analysis, and a militant standpoint. The network explains that while they do not intend to draw parallels with World War II extermination camps, other historical references are relevant, such as the "beach camps" (les camps de la plage) established by France in 1936 to detain Spanish Republicans fleeing the Franco regime. Migreurop members argue that the euphemistic use of words such as "centres" does not reflect the voluntary gathering of people fleeing war, persecution, or poverty, and that "camp" echoes states practices that predate later totalitarian practices when persons were deprived of their freedom of movement for political reasons. ${ }^{28}$ On the other hand, Migreurop uses "rétention" in its French and even Spanish publications.

\section{From euphemisms to oblivion}

Victor Klemperer, the renowned professor of literature who studied the language of the Third Reich in his diaries of life in Nazi Germany, wrote that "words can be like tiny doses of arsenic: they are swallowed unnoticed, appear to have no effect, and then after a little time the toxic reaction sets in after all." Hannah Arendt's seminal thesis on the "banality of evil" provides similar insights into the possible short- and long-term consequences of choice of language by policy-makers. Discussing Arendt's thesis, one scholar writes, "The banal vocabulary of sterilized bureaucratic euphemism such as Loesungsmoeglichkeit (possibility of solution), Sonderbehandlung (special treatment), Evakuierung (deportation) sets up distance between the bureaucrat and the victims, thereby renouncing moral responsibility." 29

Most instances of the language of immigration detention discussed in this paper are generated and used in contemporary democracies with many legal safeguards, and not in

\footnotetext{
${ }^{27}$ Committee on Civil Liberties, Justice and Home Affairs, Rapporteur: Manfred Weber, "Report on the proposal for a directive of the European Parliament and of the Council on common standards and procedures in Member States for returning illegally staying third-country nationals," European Parliament, (COM(2005)0391 - C6-0266/2005 2005/0167(COD)), 20 September 2007. http://www.europarl.europa.eu/sides/getDoc.do?language=EN\&reference=A6$0339 / 2007$

${ }^{28}$ Réseau Migreurop, “Derrière le mot 'camp' - À propos d'une controverse sur la caractérisation des lieux d'enfermement des étrangers," Les Mots Sont Importants.net, 16 January 2006. http://Imsi.net/Derriere-le-mot-camp

${ }^{29}$ David B. Levy, review of Bernard J. Bergen's The Banality of Evil: Hannah Arendt and "The Final Solution", $\mathrm{H}-$ Holocaust, August, 1999. http://www.h-net.org/reviews/showrev.php?id=3372
} 
totalitarian regimes. However, scholars and practitioners might consider revisiting some of these analyses to study whether the seemingly innocuous external packaging of policies could eventually lead to harmful consequences for the lives and health of immigration detainees, removing them from safeguards generally afforded to sentenced criminals.

One notable consequence concerns the law. Some national courts, particularly in Australia, have upheld the view that constitutional or other safeguards do not apply to persons in de facto administrative detention because they are not formally detained. ${ }^{30}$

On the other hand, a few judicial systems have begun to see through this linguistic maze. In September 2009, the European Court of Human Rights issued a watershed decision holding that Turkey's system for detaining foreign nationals in detention centres (called "foreigners' guesthouses" at the time) had no legal basis, and that as a result, the applicants had been arbitrarily detained in violation of the European Convention on Human Rights. ${ }^{31}$

A complementary trend to the euphemisms of immigration detention is the absence of any mention of this practice in many relevant official studies and statistical databases, which in effect disappears this practice from historical scrutiny. For example, the IOM helped Australia manage extra-territorial detention camps in the early 2000s, yet regular searches for "detention" on the IOM website for years during and after that period yielded no results. The EU has created a number of very efficient institutions and tools to harmonize and monitor its programmes and produce comparable data to assess the impact of common policies in immigration and asylum. While EU states are required to report on actions in relation to irregular migration, border control, and returns and expulsions, comprehensive EU state reports available through the European Migration Network website contain few references to detention. The efficient EUROSTAT statistics database collects data on "apprehensions" and "returns" but not on immigration detention. Additionally, as researchers at the Global Detention Project have frequently discovered, finding the official name of a detention site in a given country can prove problematic because nonspecific language is often employed to describe sites or governments claim to have no relevant data.

This paper suggests that in the field of immigration detention, the dissemination, role, and impact of misleading discursive strategies on policy and public perception appears to be significant and troubling. Yet, there has been very little written on the mechanics at work and consequences of language with respect to this issue. Thus, many questions remain unresolved. For instance, is it possible to concretely establish the motives authorities have followed when determining detention terminology? Do different official terminologies coexist in a single country, and if so what explains these divergences? And, most importantly, is it possible to measure the impact that euphemisms have had on the well-being of detainees, including their access to procedural safeguards?

\footnotetext{
${ }^{30}$ Al-Kateb v. Godwin, [2004] HCA 37, in which the High Court of Australia held that section 189 of the Migration Act 1958 (Cth), which requires mandatory and non-reviewable detention until either an individual obtained refugee status or is removed, was not unconstitutional.

${ }^{31}$ Abdolkhani and Karimnia v. Turkey (No.2), ECtHR Applic. No. 30471/08, 27 July 2010, in which the Court held that the detention of refugees for three months in the basement of police headquarters amounted to a violation of Article 3 of the ECHR.
} 